\title{
Synthesis, Characterization and Biological Activities of 2, 5-Dimethyl-4-Methoxy[5,6-b]Benzo[2,3-a]Pyrolo-4- Keto Thiazine-1,1-Dioxide
}

\author{
Bodunde Joseph OWOLABI ${ }^{1}$, David Iregbeyaogene IRAOYA ${ }^{1}$, Taiwo Sholagbade ADEPOJU ${ }^{1 *}$ \\ ${ }^{1}$ Chemistry Department, Federal University of Technology, Akure, Nigeria. \\ *: Corresponding Author's email address: tsadepoju@futa.edu.ng \\ DOI: 10.31364/SCIRJ/v7.i12.2019.P1219734 \\ http://dx.doi.org/10.31364/SCIRJ/v7.i12.2019.P1219734
}

\begin{abstract}
Microbial infections remain harrowing menace to health sector globally with distressing effects such as prolonged hospitalization, morbidity and high cost for treatment. The research was conducted to develop effective therapeutic agents against pathogens. Firstly, 2, 5-Dimethyl-4-sulphonyl proline anisole was synthesized from reaction between 2, 5-dimethyl-4methoxybenzene sulphonyl chloride and L-proline in basic medium. Thereafter, 2, 5-dimethyl-4-methoxy[5,6-b]benzo[2,3-a]pyrolo4-keto thiazine-1,1-dioxide was synthesized from the intermediate using thionyl chloride and triethyl amine. The synthesized compounds were characterized by FTIR and NMR. Then, antimicrobial activities of the compounds were studied. Both compounds inhibited the growth of tested bacteria and fungi. 2, 5-dimethyl-4-methoxy[5,6-b]benzo[2,3-a]pyrolo-4-keto thiazine-1,1-dioxide gave better antibacterial activities, even than commercial drug while 2, 5-Dimethyl-4-sulphonyl proline anisole exhibited stronger antifungal activities.
\end{abstract}

Keywords: Pathogens, therapeutics, infections, antimicrobials and 2, 5-dimethyl-4-methoxy[5,6-b]benzo[2,3-a]pyrolo-4-keto thiazine-1,1-dioxide

\subsection{INTRODUCTION}

Microbial infections remain harrowing menace to health sector globally with distressing effects such as prolonged hospitalization, morbidity and high cost for treatment $[1,2]$. Additionally, the capacity of pathogenic microorganisms to resist therapeutic activities of drugs has reduced the effectiveness of these drugs, making the development of new drugs a matter of necessity. Sadly speaking, the pace at which new drug is being introduced to the market is extremely low compared to the tempo at which pathogens develop resistance [3]. Thus, the development of effective antimicrobials stands as pressing need worldwide. 
However, heterocyclic compounds containing sulphur and nitrogen which are known as thiazines have been reported as potent therapeutic agents [4]. The survey of the literature has revealed thiazine derivatives as antibacterial, anti-inflammatory, antifungal, antihypertensive, neuroleptic, analgesic, antimalarial, anticancer, antiviral, antitumor, and antituberculotic agents [5-12]. Therefore, thiazine derivatives are promising antimicrobial agents. The goal of the research was to develop new derivative of thiazine and determine its antimicrobial activities.

\section{MATERIALS AND METHODS}

\section{$2.1 \quad$ MATERIALS}

All the melting points were uncorrected. The purity of synthesized compounds was determined by thin layer chromatography. Fourier Transform Infrared (FTIR) spectra were recorded with Cary model 630 spectrophotometer. Proton Nuclear Magnetic Resonance (1H NMR) spectra were obtained on Agilent NMR spectrometer (400 MHz).

\subsection{Synthesis of 2, 5-dimethyl-4-methoxylbenzene sulphonylchloride}

The synthesis of 2, 5-dimethyl-4-methoxylbenzene sulphonylchloride (1) had been described in our previous work [13].

\subsection{Synthesis of 2, 5-Dimethyl-4-Sulphonyl Proline Anisole}

L-proline (2.5g) was dissolved in sodium hydroxide solution (5\%) with continuous stirring. 2, 5-dimethyl-4-methoxylbenzene sulphonylchloride $(5 \mathrm{~g})$ was added to the solution. The reaction was carried out for $6 \mathrm{~h}$ on a magnetic stirrer at room temperature. Thereafter, the resulting mixture was neutralized, filtered and washed with distilled water. Colourless oily liquid, Yield: $74.5 \%$, $\mathrm{R}_{\mathrm{f}}$ : $0.87\left(\mathrm{CH}_{3} \mathrm{COCH}_{3}, \mathrm{C}_{6} \mathrm{H}_{14}\right.$ and $\left.\mathrm{CHCl}_{3}, 1: 1: 1\right)$, FTIR $\left(\mathrm{KBr}, \mathrm{cm}^{-1}\right): 2935.6\left(\mathrm{sp}^{3} \mathrm{C}-\mathrm{H}\right), 650.0$ (Ar-C-H, bending vibration), $3419.79(\mathrm{O}-\mathrm{H})$, $1147.6(\mathrm{C}-\mathrm{O}-\mathrm{C}), 1041.5(\mathrm{~S}=\mathrm{O})$ and $1608.6(\mathrm{C}=\mathrm{O}) . \delta \mathrm{H}\left(\mathrm{CdCl}_{3}, \mathrm{ppm}\right): 7.17(1 \mathrm{H}, \mathrm{s}, \mathrm{Ar}-\mathrm{H}), 7.70(\mathrm{H}, \mathrm{s}, \mathrm{Ar}-\mathrm{H}), 3.83\left(3 \mathrm{H}, \mathrm{s},-\mathrm{OCH}_{3}\right), 2.15$ $\left(3 \mathrm{H}, \mathrm{s}, \mathrm{CH}_{3}\right), 2.57\left(3 \mathrm{H}, \mathrm{s},-\mathrm{CH}_{3}\right), 3.17\left(2 \mathrm{H}, \mathrm{s},-\mathrm{CH}_{2}\right), 3.38\left(2 \mathrm{H}, \mathrm{s},-\mathrm{CH}_{2}\right)$ and $3.17\left(2 \mathrm{H}, \mathrm{s},-\mathrm{CH}_{2}\right)$.

\subsection{Synthesis of 2, 5-Dimethyl-4-Methoxy[5,6-b]Benzo[2,3-a]Pyrolo-4-Keto Thiazine-1,1-Dioxide}

2, 5-Dimethyl-4-Sulphnyl proline anisole was mixed with thionyl chloride $(10 \mathrm{ml})$ and the mixture was refluxed for $3 \mathrm{~h}$. Then, thionyl chloride was distilled. Tri-ethyl amine (TEA) was added to the resulting compound (2, 5-dimethyl-4-sulphnyl proline chloride) and refluxed for $6 \mathrm{~h}$. The resulting mixture was poured into cold water and extracted with chloroform (20 $\mathrm{ml} \mathrm{X} \mathrm{2).} \mathrm{The} \mathrm{final} \mathrm{compound}$ was recovered from chloroform. Dark brown, M.P: $68^{\circ} \mathrm{C}$, Yield: $90 \%, \mathrm{R}_{\mathrm{f}}: 0.80\left(\mathrm{CH}_{3} \mathrm{COCH}_{3}, \mathrm{nC}_{6} \mathrm{H}_{6}\right.$ and $\left.\mathrm{CHCl}_{3}, 1: 1: 1\right), \mathrm{FTIR}(\mathrm{KBr}$, $\mathrm{cm}^{-1}$ ): 2900.0 (sp3 C-H), 750.3 (Ar-C-H, bending vibration), $1134.1(\mathrm{C}-\mathrm{O}-\mathrm{C}), 1053.1(\mathrm{~S}=\mathrm{O})$ and $1734.0(\mathrm{C}=\mathrm{O}) .8 \mathrm{H}\left(\mathrm{CdCl} l_{3}, \mathrm{ppm}\right)$ : $7.24(1 \mathrm{H}, \mathrm{m}, \mathrm{Ar}-\mathrm{H}), 3.82\left(3 \mathrm{H}, \mathrm{m},-\mathrm{OCH}_{3}\right), 2.35\left(3 \mathrm{H}, \mathrm{m}, \mathrm{CH}_{3}\right), 2.66\left(3 \mathrm{H}, \mathrm{m},-\mathrm{CH}_{3}\right), 3.11\left(2 \mathrm{H}, \mathrm{m},-\mathrm{CH}_{2}\right), 3.75\left(2 \mathrm{H}, \mathrm{m},-\mathrm{CH}_{2}\right)$ and 3.06 $\left(2 \mathrm{H}, \mathrm{m},-\mathrm{CH}_{2}\right)$.

\subsection{Evaluation of the Antibacterial Activities}


The synthesized compounds were screened for antibacterial activities against six bacteria. The bacteria used for this experiment include: Staphylococcus aureus enterobacter aerogenes, pseudomonous glycinear, erwinia carotouora, clavibacter michinganensis, salmonella typii. Agar well diffusion method as described by Murray et al. (1995) was used [14]. Amoksiklov (amoxicillin 250mg and clavulanic acid $125 \mathrm{mg}$ ) was used as a standard.

\subsection{Evaluation of the Antifungal Activities}

The selected fungi of choice used for this experiment were; phytophthora pulmivora, fusarium vasinfectum, and collectothricum lindimthianum, poisoned food techniques [14] was used for this investigation with Mamcozeb as standard.

\subsection{RESULTS AND DISCUSSION}

\subsection{Synthesis and Characterization of 2, 5-Dimethyl-4-Sulphonyl Proline Anisole}

2, 5-Dimethyl-4-sulphonyl proline anisole (2) was synthesized from reaction between 2, 5-dimethyl-4-methoxybenzene sulphonyl chloride and L-proline in basic medium as shown in scheme 1 below. The FTIR spectrum (Fig. 1) confirmed the presence of carboxylic acid group present in compound 2 via the characteristic band of hydroxyl group at $3419.79 \mathrm{~cm}^{-1}$ and carbonyl group at $1608.63 \mathrm{~cm}^{-1}$. The presence of benzene ring in the structure was established by sharp absorption band at $650.01 \mathrm{~cm}^{-1}$. The absorption band at $1147.65 \mathrm{~cm}^{-1}$ confirmed the presence of ether linkage (C-O-C) and the absorption at $1041.56 \mathrm{~cm}^{-1}$ confirmed the presence of sulphonyl group $(\mathrm{S}=\mathrm{O})$. The ${ }^{1} \mathrm{H}$ NMR spectrum (Fig. 2) showed the presence of saturated protons in the range of 2.13 ppm to 4.36 ppm, confirming the presence of methyl and methylene protons present in compound 2 . The peaks between 7.17 ppm and 7.70 ppm established the presence of aromatic protons.

WwW.scirj.org 

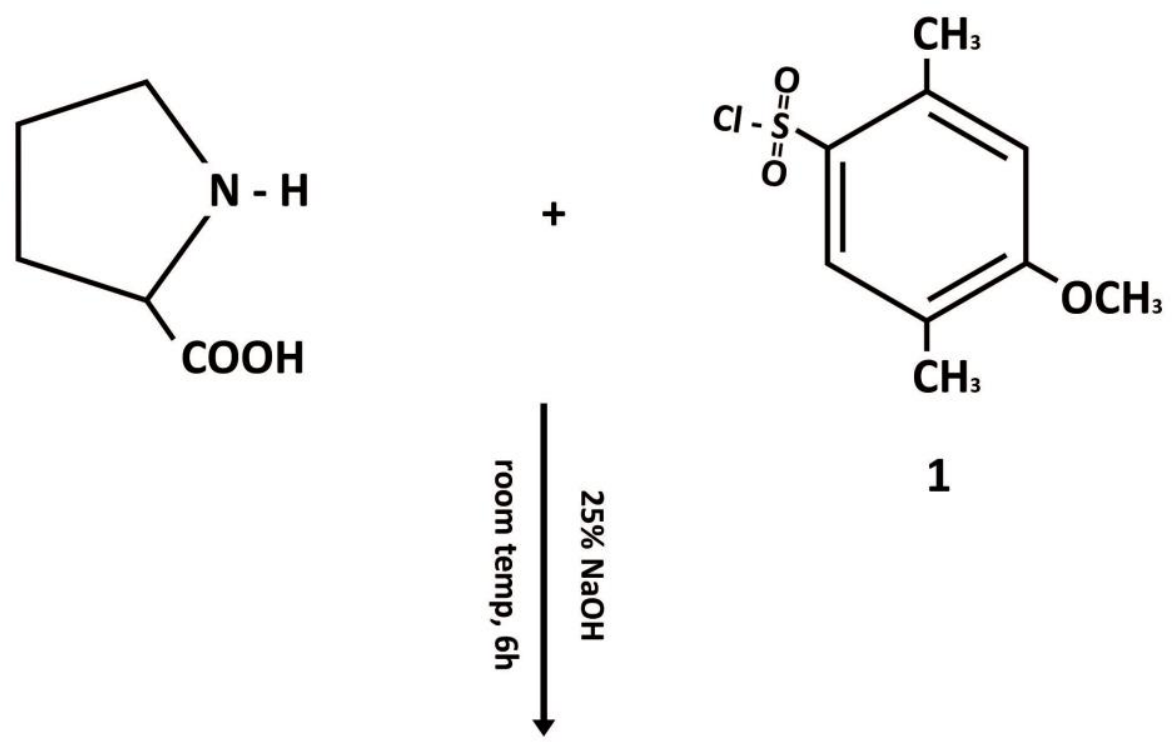

1

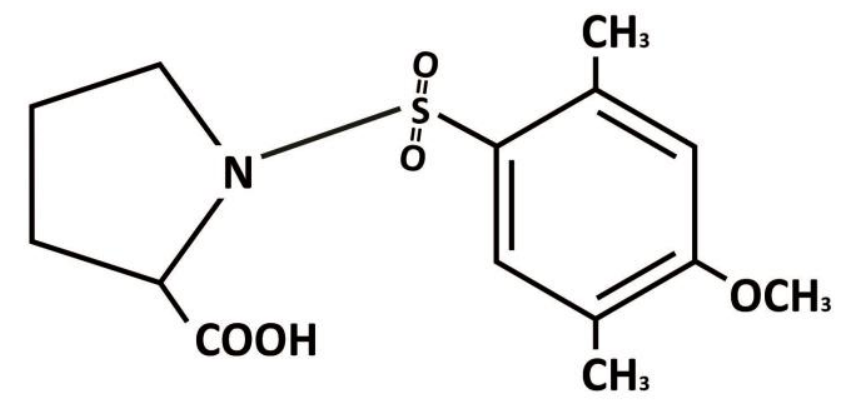

2

Scheme 1: Synthesis of 2, 5-dimethyl-4-sulphonyl proline anisole 


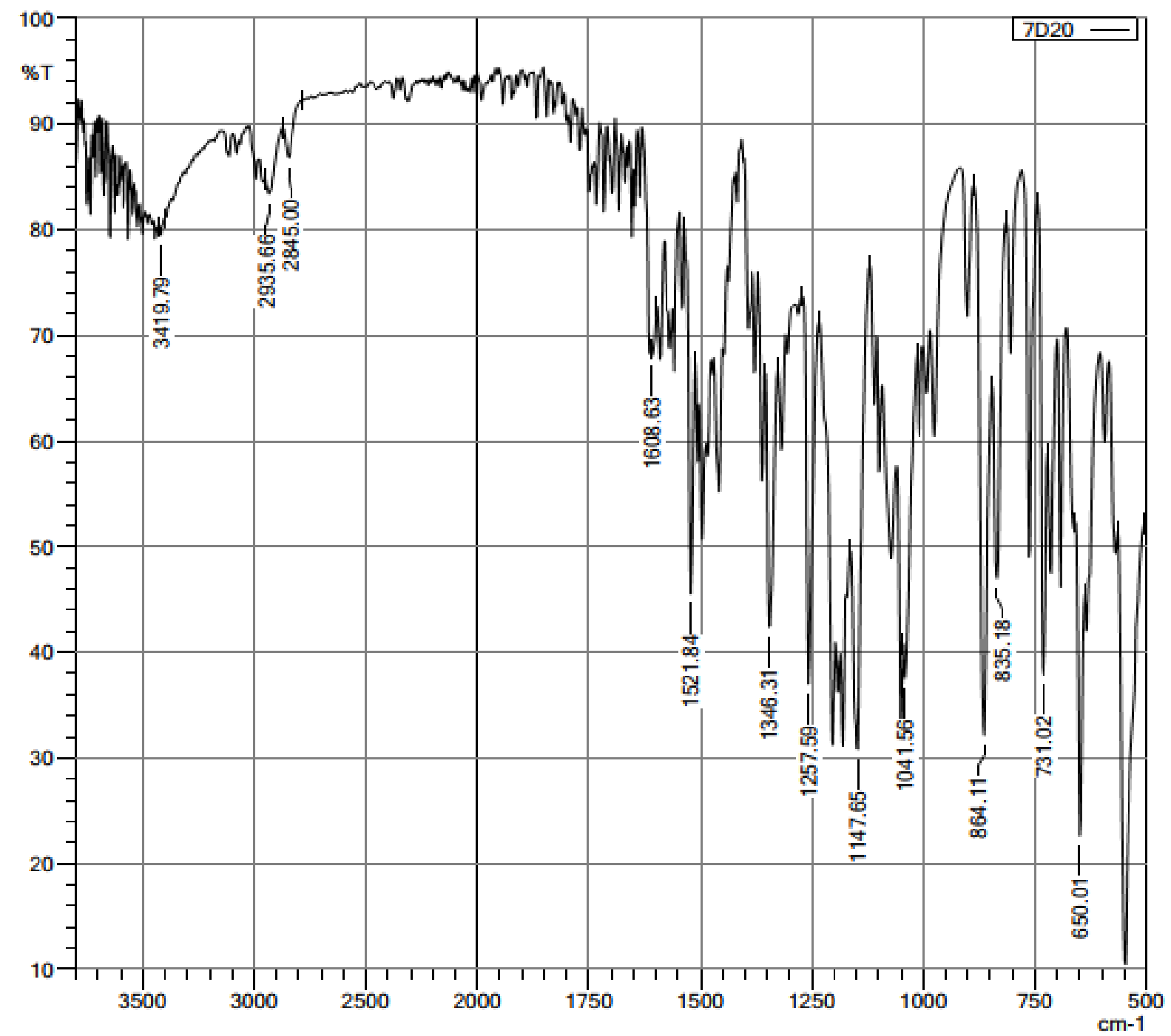

Figure

1: FTIR spectrum of 2, 5-dimethyl-4-sulphonyl proline anisole 


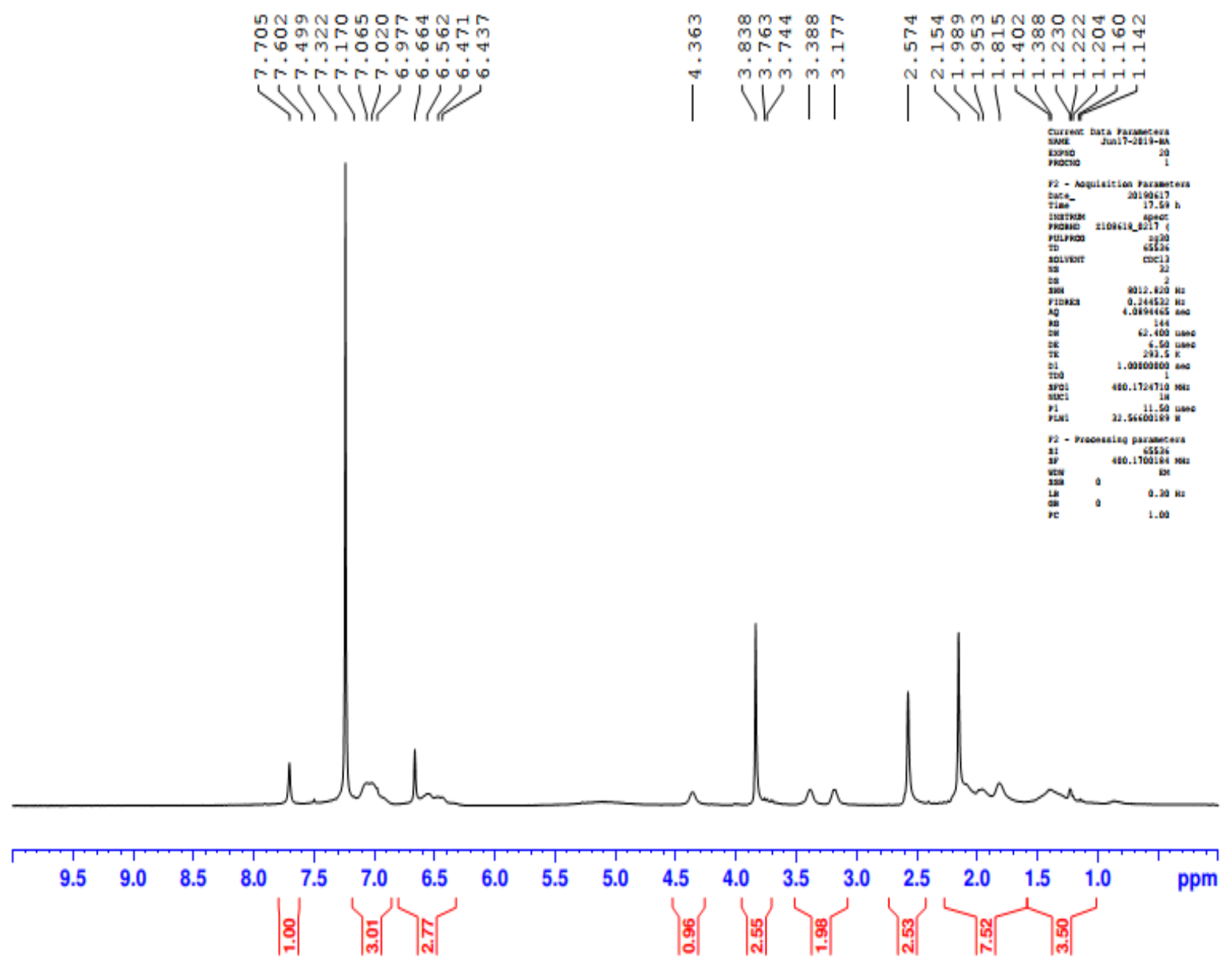

Proton NMR spectrum of 2, 5-dimethyl-4-sulphonyl proline anisole

\subsection{Synthesis of 2, 5-Dimethyl-4-Methoxy[5,6-b]Benzo[2,3-a]Pyrolo-4-Keto Thiazine-1,1-Dioxide}

The synthetic procedure for synthesis of 2, 5-dimethyl-4-methoxy[5,6-b]benzo[2,3-a]pyrolo-4-keto thiazine-1,1-dioxide compound 3 was depicted in scheme 2. The FTIR spectrum (Fig. 3) showed absorption band at $750.31 \mathrm{~cm}^{-1}$, confirming the benzene ring as present in compound 3. Band stretch at $1734.01 \mathrm{~cm}^{-1}$ revealed the presence of a ketone. The absorption bands at 1134.14 and $1053.13 \mathrm{~cm}^{-1}$ $1053.13 \mathrm{~cm}^{-1}$ confirmed the presence of ether linkage (C-O-C) and sulphonyl group ( $\left.\mathrm{S}=\mathrm{O}\right)$ respectively. The ${ }^{1} \mathrm{H}$ NMR spectrum (Fig. 4) showed the presence of saturated protons in the range of $2.35 \mathrm{ppm}$ to $3.82 \mathrm{ppm}$, confirming the presence of methyl and methylene protons present in compound 3. The multiplet peaks in the region of 7.24 established the presence of aromatic proton present the structure. 


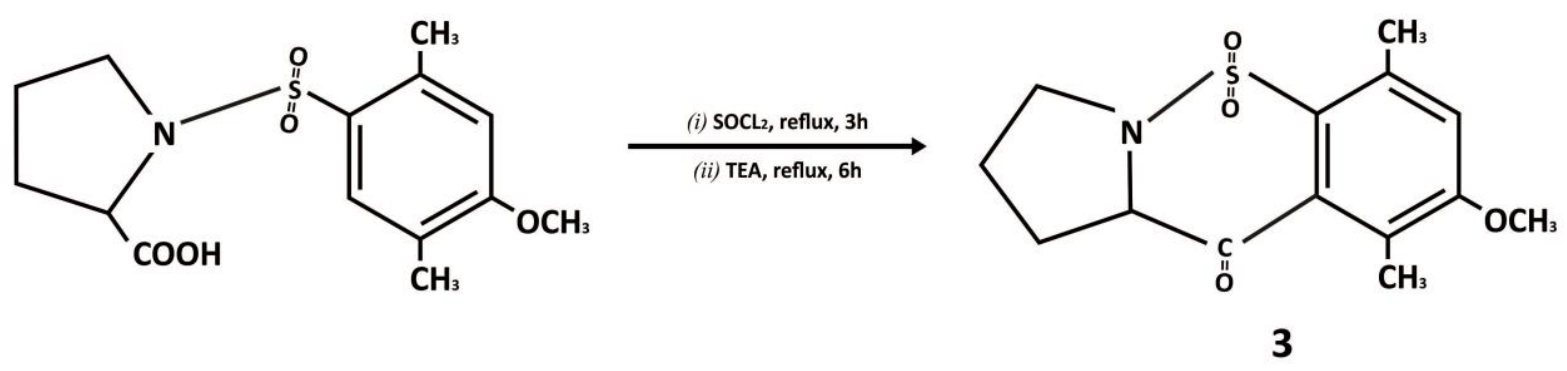

Scheme 2: Synthesis of 2, 5-dimethyl-4-methoxy[5,6-b]benzo[2,3-a]pyrolo-4-keto thiazine-1,1-dioxide 


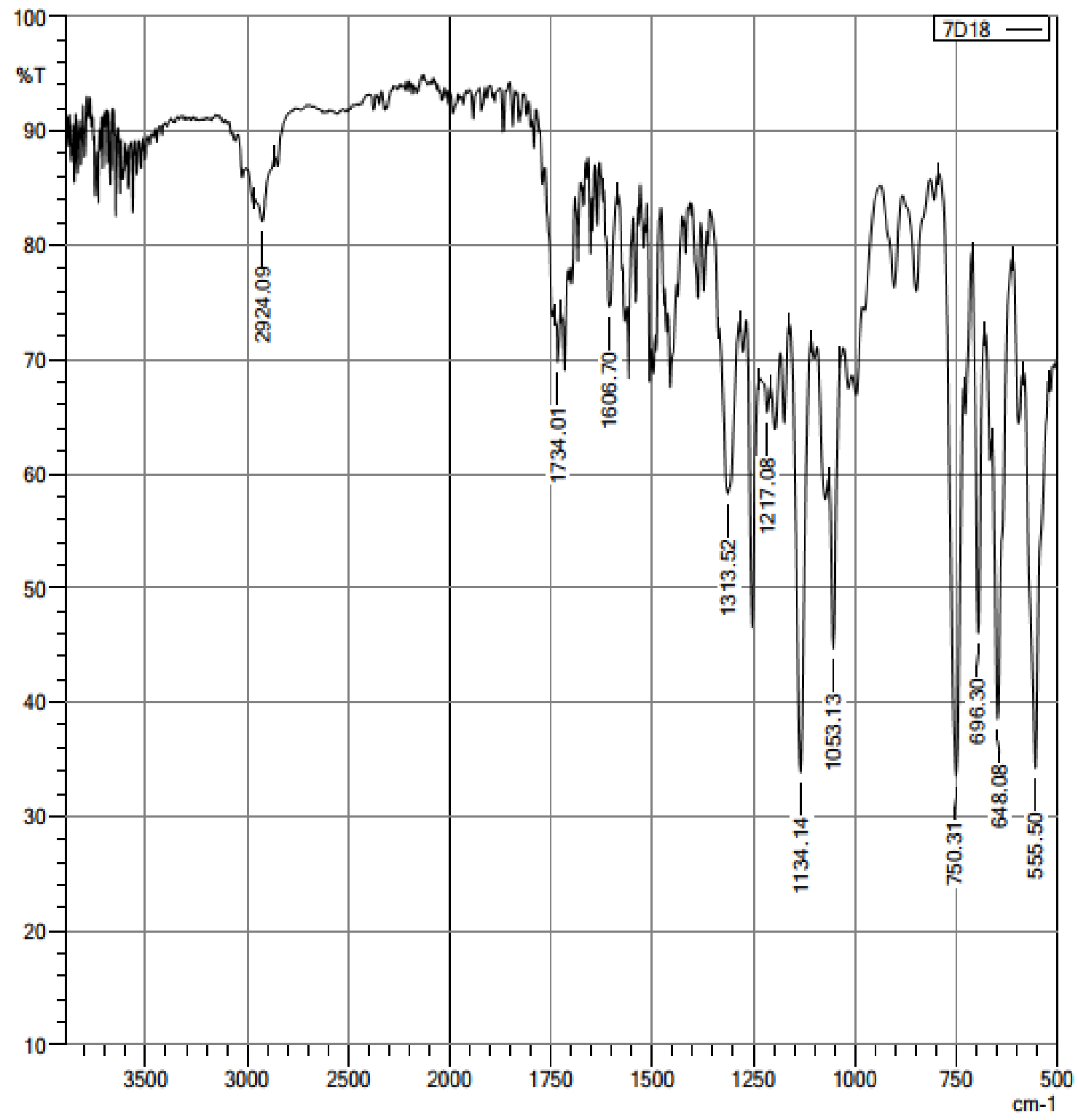

Figure 3: FTIR

spectrum of 2, 5-dimethyl-4-methoxy[5,6-b]benzo[2,3-a]pyrolo-4-keto thiazine-1,1-dioxide 


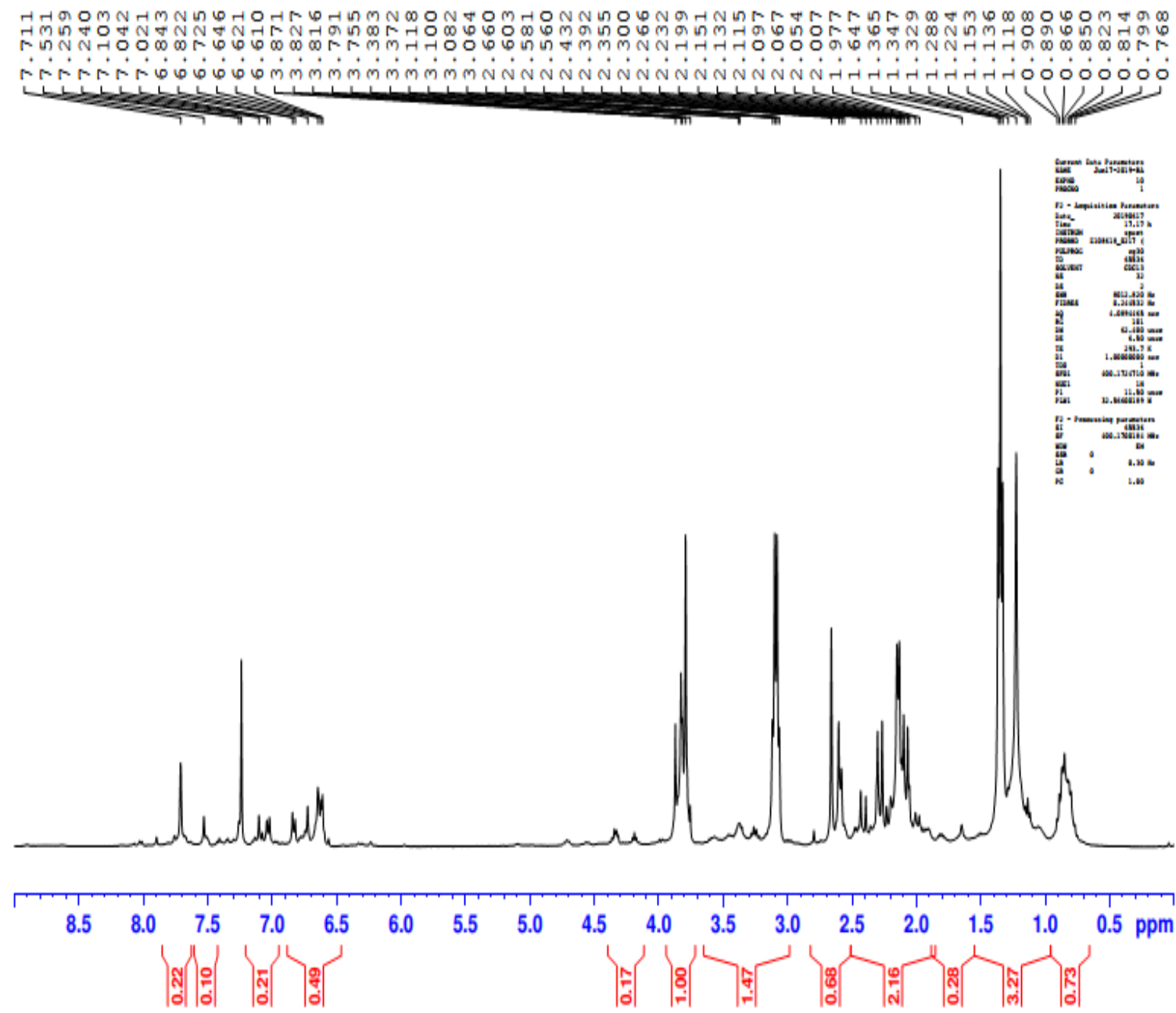

Figure 4: Proton

NMR of 2, 5-dimethyl-4-methoxy[5,6-b]benzo[2,3-a]pyrolo-4-keto thiazine-1,1-dioxide

\subsection{Evaluation of the Antibacterial Activities}

The synthesized compounds (2, 3) were tested for their antibacterial activities against six bacteria: Staphylococcus aureus, Enterobacter aerogenes, Pseudomonous glycinear, Erwinia carotouora, Clavibacter michinganensis, Salmonella typii. using amoksiklov (amoxicillin 250mg and cluvulanic acid 125mg) as a standard drug. The inhibitory results are reported in Table 1. From the table, it could be deduced that the compounds possessed antibacterial properties. Compound 2 generally appeared to be more potent that compound $\mathbf{3}$ and standard. It showed strong activities against both Gram-negative and Gram-positive bacteria tested. The activities of compound $\mathbf{3}$ against Staphylococcus aureus, Pseudomonous glycinear and Clavibacter michinganensis were higher compared to activities of standard drug.

Table 1: Results of Antibacterial Activities of Synthesized Compounds

\begin{tabular}{cccc}
\hline Sample & Compound & Compound & Amoksiklov \\
& $\mathbf{2}(\mathrm{mm})$ & $\mathbf{3}(\mathrm{mm})$ & \\
& &
\end{tabular}




\begin{tabular}{lccc}
\hline Staphylococcus aureus & $18^{\mathrm{d} \pm 0.58}$ & $16.8^{\mathrm{d}} \pm 0.14$ & $14^{\mathrm{e}} \pm 0.58$ \\
Enterobacter aerogenes & $41^{\mathrm{a}} \pm 0.58$ & $20.5^{\mathrm{c}} \pm 0.29$ & $22^{\mathrm{c}} \pm 0.58$ \\
Pseudomonous glycinear & $22.5^{\mathrm{c}} \pm 0.29$ & $13.5^{\mathrm{e}} \pm 0.29$ & $9^{\mathrm{f}} \pm 0.58$ \\
& & & \\
Erwinia carotouora & $22.5^{\mathrm{c}} \pm 0.29$ & $13.5^{\mathrm{e}} \pm 0.29$ & $17.5^{\mathrm{d}} \pm 0.29$ \\
& & & \\
Clavibacter michinganensis & $28.5^{\mathrm{b}} \pm 0.29$ & $29^{\mathrm{b}} \pm 0.58$ & $25.5^{\mathrm{b}} \pm 0.29$ \\
& & & \\
Salmonella typii & $42.5^{\mathrm{a}} \pm 2.60$ & $33.5^{\mathrm{a}} \pm 1.44$ & $41.5^{\mathrm{a}} \pm 2.60$
\end{tabular}

\section{$a, b, c=$ Means within the same row with different superscripts are significantly $(p<0.05)$ different.} Compound 2: 2,5-dimethyl-4-sulphonyl proline anisole.

Compound 3: 2, 5-dimethyl-4-methoxy [5,6-b]benzo[2,3-a]pyrolo-4-ketothiazine-1,1-dioxide

Amoksiklov: Standard used.

\subsection{Evaluation of the Antifungal Activities}

The synthesized compounds $(\mathbf{2}, \mathbf{3})$ were screened for their antifungal activities against three pathogenic fungi, Collectotrichuin lindimuthianum, Phytophthora palmivora and Fusarium vasinfectium using poisoned food technique. Mamcozeb was used as a standard drug. Standard drugs exhibited higher potency than both compounds. However, compound $\mathbf{3}$ demonstrated significantly higher inhibition than compound $\mathbf{2}$. Compound $\mathbf{2}$ showed low fungal inhibition.

Table 2: Results Antifungal Activities of the Synthesized Compounds

\begin{tabular}{|c|c|c|c|c|c|}
\hline \multirow{2}{*}{$\begin{array}{l}\text { a,b,c= Means } \\
\text { same row with } \\
\text { superscripts } \\
\text { significantly } \\
\text { different. } \\
\text { Compound 2: }\end{array}$} & Sample & $\begin{array}{c}\text { Compound } \\
2(\%)\end{array}$ & $\begin{array}{c}\text { Compound } \\
\mathbf{3}(\%)\end{array}$ & Mancozeb & \multirow{2}{*}{$\begin{array}{l}\text { within the } \\
\text { different } \\
\text { are } \\
(\mathbf{p}<0.05)\end{array}$} \\
\hline & Phytophthora palmivora & $6.58^{\mathrm{c}} \pm 0.82$ & $21.8^{\mathrm{b}} \pm 0.10$ & $100^{\mathrm{a}} \pm 0$ & \\
\hline 4-sulphonyl & Fusarium vasinfectium & $4.69^{c} \pm 0.30$ & $81.1^{\mathrm{b}} \pm 0.66$ & $100^{\mathrm{a}} \pm 0$ & proline anisole \\
\hline $\begin{array}{l}\text { Compound 3: } \\
\text { 4-methoxy }\end{array}$ & & & & & $\begin{array}{r}\text { 2, 5-dimethyl } \\
{[5,6}\end{array}$ \\
\hline $\begin{array}{l}\text { b]benzo[2,3- } \\
\text { ketothiazine- }\end{array}$ & Collectotrichuin lindimuthianum & $2.65^{\mathrm{c}} \pm 0.33$ & $70.1^{\mathrm{b}} \pm 0.10$ & $77.7^{\mathrm{b}} \pm 0.41$ & $\begin{array}{l}\text { a]pyrolo-4- } \\
\text { 1,1-dioxide }\end{array}$ \\
\hline
\end{tabular}

Mancozeb: Standard used.

4.0 CONCLUSION

www.scirj.org 
2,5-Dimethyl-4-Sulphonyl proline anisole (2) and 2,5-Dimethyl-4-methoxy[5,6-b]benzo[2,3-a] pyrolo-4-ketothiazine-1,1-dioxide (3) were successfully synthesized. Their structures were confirmed by spectral data. Compound $\mathbf{2}$ and compound $\mathbf{3}$ gave percentage yield of $74.5 \%$ and $90 \%$ respectively. The results of antibacterial activities showed that both synthesized compounds were potential antibacterial agents. However, the results of antifungal activity only revealed compound $\mathbf{3}$ as potential antifungal agent against plant pathogenic fungi.

\subsection{REFERENCE}

1. Ling L. L, Schneider T, Peoples A. J, Spoering A. L, Engels I, Conlon B. P, Mueller A, Schäberle T. F, Hughes D. E, Epstein S, Jones M, Lazarides L, Steadman V. A, Cohen D. R, Felix C. R, Fetterman K. A, Millett W. P, Nitti A. G, Zullo A. M, Chen C, Lewis K. (2015). A new antibiotic kills pathogen without detectable resistance. Nature 517:455-462. 2. Vincent J. L, Rello J, Marshall J, Silva E, Anzueto A, Martin C. D, Moreno R, Lipman J, Gomersall C, Sakr Y, Reinhart K (2009). International study of the prevalence and outcomes of infection in Intensive Care Units. JAMA 302(21): 2323-2329.

3. Sharma P. K. and Kaur G. (2017). A review on antimicrobial activities of important thiazines based heterocycles. Drug Invention Today. 9(3):23-25.

4. Sayaji S. D. and Pravina B. P. (2013). Synthesis and antimicrobial activity of thiazine derivatives. J. Chem. Pharm. Res. $5(4): 171-174$

5. Matysiak J. (2006) Synthesis, antiproliferative and antifungal activities of some 2-(2,4-dihydroxyphenyl)-4H-3,1benzothiazines. Bioorg Med Chem. 14:2613-9.

6. Macchiarulo A, Costantino G, Fringuelli D, Vecchiarelli A, Schiaffella F, Fringuelli R. 1,4-Benzothiazine and 1,4benzoxazine imidazole derivatives with antifungal activity: A docking study. Bioorg Med Chem.10:3415-23.

7. Rathore M. M., RajputPP P. R. and Parhate V. V. (2015) Synthesis characterization of some nitro-substituted-1, 3-thiazines and their antimicrobial activities. IJSEAS. 1(8):423-428.

8. Al-Hiari Y. M., Qaisi A. M., Abu Shuheil M. Y., El-Abadelah M. M., Voelter, W. (2007). Synthesis and antibacterial potency of 4-methyl-2,7-dioxo-1,2,3,4,7,10-hexahydropyrido[2,3-f]quinoxaline-8-carboxylic acid, selected [a]-fused heterocyles and acyclic precursors. Z. Naturforsch. Sect. B J. Chem. Sci. 62:1453-1458.

9. Fringuelli R., Schiaffella F., Vecchiarelli A. (2001). Antifungal and immunomodulating activities of 1, 4-benzothiazine azole derivatives: Review. J Chemother. 13:9-14.

10. Rathore B. S., Kumar M. (2006) Synthesis of 7-chloro-5trifluoromethyl/7-fluoro/7-trifluoromethyl-4H-1,4benzothiazines as antimicrobial agents. Bioorg Med Chem. 14:5678-82.

11. Niewiadomy, A., Matysiak, J., Karpinska, M. M. (2011). Synthesis and anticancer activity of new 2-aryl-4H3,1benzothiazines. Arch. Pharm. 344:224-230. 
12. Hirokawa Y, Kinoshita H, Tanaka T, Nakamura T, Fujimoto K, Kashimoto S, et al. (2009). Pleuromutilin derivatives having a purine ring. Part 2: Influence of the central spacer on the antibacterial activity against Gram-positive pathogens. Bioorg Med Chem Lett. 19:170-4.

13. Owolabi B. J., Abdulwahab A. O. and Adepoju T. S. (2019). Synthesis, characterization and antimicrobial activities of 2, 5dimethyl-4-methoxylbenezene thioacetic acid. Global scientific. 7(9):66-86.

14. Murray P. R., Baron E. J., Faller M. A., Terrover F. C., and Yolken H. R., (1995).

Mannual of clinical microbiology. 15-18 ASM press D. C. 